\title{
Development of Recombinant Coat Protein Antibody Based IC-RT-PCR and Comparison of its Sensitivity with Other Immunoassays for the Detection of Papaya Ringspot Virus Isolates from India
}

\author{
M. Sreenivasulu and D. V. R. Sai Gopal* \\ Department of Virology, Sri Venkateswara University, Tirupati-517 502, A. P., India \\ (Received on December 9, 2009; Accepted on February 13, 2010)
}

Papaya ringspot virus (PRSV) causes the most widespread and devastating disease in papaya. Isolates of PRSV originating from different geographical regions in south India were collected and maintained on natural host papaya. The entire coat protein (CP) gene of Papaya ringspot virus-P biotype (PRSV-P) was amplified by RTPCR. The amplicon was inserted into pGEM-T vector, sequenced and sub cloned into a bacterial expression vector pRSET-A using a directional cloning strategy. The PRSV coat protein was over-expressed as a fusion protein in Escherichia coli. SDS-PAGE gel revealed that $\mathrm{CP}$ expressed as a $\sim 40 \mathrm{kDa}$ protein. The recombinant coat protein ( $\mathrm{rCP}$ ) fused with $6 x$ His-tag was purified from $E$.coli using Ni-NTA resin. The antigenicity of the fusion protein was determined by western blot analysis using antibodies raised against purified PRSV. The purified rCP was used as an antigen to produce high titer PRSV specific polyclonal antiserum. The resulting antiserum was used to develop an immunocapture reverse transcription-polymerase chain reaction (IC-RTPCR) assay and compared its sensitivity levels with ELISA based assays for detection of PRSV isolates. ICRT-PCR was shown to be the most sensitive test followed by dot-blot immunobinding assay (DBIA) and plate trapped ELISA.

Keywords : IC-RT-PCR, Papaya ringspot virus, polyclonal antibodies, recombinant coat protein

The papaya and watermelon biotypes of Papaya ringspot virus (PRSV-P\&W) cause major disease in papaya and cucurbits, respectively in tropical and subtropical regions including Indian subcontinent that result in significant yield losses (Gonsalves, 1998; Varma, 1988). The disease has become a major threat to papaya cultivation throughout India by rendering orchards economically unproductive. PRSV was first reported in western India in 1958 (Capoor and Vrama, 1958) and since then it has spread to different

\footnotetext{
*Corresponding author.

Phone) 91-0877-2289452, FAX) 91-0877-2249611

E-mail)profdvrsaigopal@rediffmail.com
}

geographical locations irrespective of the agro-climatic conditions result in crop losses of up to $85-90 \%$ (Hussain and Varma, 1994). PRSV, a definitive member of the genus Potyvirus of the family Potyviridae (van Regenmortel, 2000), is non-persistently transmitted by numerous species of aphids in nature and particles are flexuous filamentous rods of about $780 \times 12 \mathrm{~nm}$ in size (Gonsalves and Ishii, 1980). The virions contain a positive sense, single stranded RNA genome approximately $10.3 \mathrm{~kb}$ in length surrounded by a coat protein (CP) consisting of a single protein subunit of molecular weight $36 \mathrm{kDa}$ (Yeh et al., 1992). Based on the host range specificity, PRSV is classified into two types that cannot be distinguished by serological methods. PRSV type $P$ infects papaya and has a limited experimental host range in cucurbits. PRSV type $\mathrm{W}$ infects wide range of economically important cucurbit crops, but, it does not infect papaya (Purcifull et al., 1984). Although both types are serologically related, observations suggested that papaya is the major source for the spread of PRSV type P (Yeh et al., 1984).

The efficient production of good quality antiserum to potyviruses is an uphill task under conventional methods due to difficulty to purify sufficient quantities of their filamentous particles. The virus particles are relatively low stable and they tend to aggregate with plant debris or among the elongated virus particles themselves. This leads to considerable losses of virus during the purification process, thereby requiring only gentle and highly labor-intensive purification methods, with special attention to removal of plant proteins. The purification of PRSV from papaya leaf was shown to be difficult as papaya latex causes aggregation of virus particles during purification steps. At higher temperatures, especially in south Indian climatic conditions, propagation of PRSV on alternative cucurbitaceous plants for purification is also not practical. Polyclonal antibodies raised against purified virions contaminated with host tissue components, cross react with host antigens and often give variable background reactions, thus limiting their use in ELISA based diagnostic methods. The difficulties associated with the development of antibodies of good quality against virions purified by conventional 
methods, can be overcome by cloning and expression of $\mathrm{CP}$ gene in E. coli and using the expressed $\mathrm{CP}$ as an antigen for immunization. Though immunological methods were found to be most popular, inexpensive and widely used techniques for detection of plant viruses, they are comparatively less sensitive than PCR based methods and sometimes fail to detect virus in samples at low concentrations. RT-PCR, however, is not a suggestible method for routine large scale testing of virus samples as the extraction of total nucleic acid is expensive, time consuming and not amenable for processing of a large number of samples. To overcome the difficulties and drawbacks to the application of ELISA and RT-PCR techniques in the study and diagnosis of plant viral pathogens with RNA genomes, IC-RT-PCR was developed as an alternative approach for sensitive detection and as well as for batch testing of several RNA viruses (Mumford and Seal, 1997; Nolasco et al., 1993).

The present paper report the expression of PRSV CP in E. coli, the use of the purified recombinant protein as an immunogen for the production of a high titer PRSV specific polyclonal antiserum and the development of recombinant coat protein antibody based IC-RT-PCR for diagnosis of PRSV isolates. We report that the IC-RT-PCR technique is more sensitive compared to ELISA and DBIA.

\section{Materials and Methods}

Virus isolates and maintenance. PRSV-type $\mathrm{P}$ isolates used in this study were collected from commercial papaya orchards in South Indian states. All isolates were maintained on their natural host papaya in an insect-proof glasshouse by mechanical inoculation. Leaves from papaya plants showing symptoms such as vein clearing, mild mottle, leaf blistering, leaf distortion and filiformy were collected from Kodur (PRSV-APRa), Kovvur (PRSV-APKo), and Hyderabad (PRSV-APTe) in Andhra Pradesh state; Hospet (PRSVKAHo) and Gulbarga (PRSV-KAGu) in Karnataka state; Tiruvallur (PRSV-TATi) in Tamil Nadu state and Calicut
(PRSV-KECa) in Kerala state of south India.

RNA extraction and RT-PCR. The total RNA from 100 mg of fresh healthy and PRSV (PRSV-APRa isolate) infected papaya leaf tissue was isolated using RNeasy plant mini kit according to the manufacturer's instructions (Qiagen). The resulting total RNA was incubated with oligo (dT) primer at $70^{\circ} \mathrm{C}$ for $5 \mathrm{~min}$ and snap-chilled on ice for 2 min. cDNA was synthesized using M-MuLV reverse transcriptase (Fermentas) at $37^{\circ} \mathrm{C}$ for $1 \mathrm{~h}$. The sequence and position of oligonucleotide primers used to amplify the $3^{\prime}$ terminal region encoding $\mathrm{C}$-terminal region of $\mathrm{NIb}$, complete CP and 3' UTR (size $\sim 1.7 \mathrm{~kb}$ ) are shown in Table 1. Two to three $\mu$ l of cDNA was amplified in a $50 \mu$ reaction volume containing 2.5 units of Taq DNA polymerase (Fermentas), 10 pmol of forward (PRSV-F) and reverse primers (PRSV-R), $2.25 \mathrm{mM} \mathrm{MgCl}{ }_{2}$ and $0.2 \mathrm{mM}$ each of the dNTPs. PCR amplification conditions included an initial denaturation cycle of $2 \mathrm{~min}$ at $94^{\circ} \mathrm{C}$ followed by 35 cycles of denaturation for $30 \mathrm{sec}$ at $94^{\circ} \mathrm{C}$, annealing for $30 \mathrm{sec}$ at $45^{\circ} \mathrm{C}$ and extension for $1 \mathrm{~min}$ at $72^{\circ} \mathrm{C}$ with a final extension of $30 \mathrm{~min}$ at $72^{\circ} \mathrm{C}$.

Cloning and nucleotide sequencing. The PCR-amplified fragments were purified using QIAquick PCR purification kit (Qiagen) and then cloned into pGEM-T easy cloning vector (Promega) according to the manufacturer's instructions. The resulting recombinant plasmid (pGEM-APRa) was transformed into $E$. coli strain $\mathrm{DH}_{5} \alpha$ cells. The selected clones with expected size DNA inserts were sequenced using T7 and SP6 universal primers and a gene specific primer PRSV-R $\mathrm{R}_{\mathrm{i}}$ at MWG Biotech Pvt. Ltd., Bangalore.

Cloning of PRSV CP gene in an expression vector. Based on the sequence data of 3 ' terminal regions $(\sim 1.7 \mathrm{~kb})$ of PRSV-APRa isolate (Accession No. AY839863), a primer pair was designed for the site-specific amplification of the entire $\mathrm{CP}$ coding region. The specific recognition

Table 1. Description of oligonucleotide primers used in this study. Primers PRSV-F, PRSV-R and PRSV-Ri were designed from the PRSV genomic sequence in the GenBank (Accession No. NC_001785) while CP-F and CP-R were designed based on the sequence of PRSV-APRa isolate (Accession No.AY839863)

\begin{tabular}{clcc}
\hline \hline Primers & \multicolumn{1}{c}{ Sequence $^{\mathrm{a}}$} & Orientation & Sequence Position \\
\hline PRSV-F & 5' ATCACAATGTATTACGC 3' & Sense & $8615-8631$ \\
PRSV-R & 5' CTCTCATTCTAAGAGGCTC 3' & Antisense & $10311-10329$ \\
'PRSV-R & 5' CCGCGTTACTRAAGTGAGCCAT 3' & Antisense & $9798-9819$ \\
CP-F & 5' CGGGATCCTCAAAAAGTTTAGATGA 3' & Sense & $9197-9213$ \\
CP-R & 5' AACCCAAGCTTTTAGTTGCGCATA 3' & Antisense & $10111-10123$ \\
\hline
\end{tabular}

\footnotetext{
${ }^{a}$ Underlined sequences represent the restriction sites for BamH1 and Hind III in CP-F and CP-R, respectively.

${ }^{\mathrm{b}}$ Primer used for sequencing.

IUPAC Code for mixed bases

$\mathrm{R}=\mathrm{A} / \mathrm{G}$
} 
sequences for the restriction enzymes Bam $\mathrm{H} 1$ and Hind III (underlined) were created at the $5^{\prime}$ end of the sense (CP-F) and anti sense primer (CP-R), respectively to facilitate directional cloning of the $\mathrm{CP}$ gene into the expression vector. The CP gene was amplified from clone pGEM-APRa using the above primer pair under the following conditions: initial denaturation cycle of $10 \mathrm{~min}$ at $94^{\circ} \mathrm{C}$ followed by 35 cycles of denaturation for $30 \mathrm{sec}$ at $94^{\circ} \mathrm{C}$, annealing for $45 \mathrm{sec}$ at $55^{\circ} \mathrm{C}$ and extension for $1 \mathrm{~min}$ at $72^{\circ} \mathrm{C}$ with a final extension of $10 \mathrm{~min}$ at $72^{\circ} \mathrm{C}$. The amplified $\mathrm{CP}$ gene was cloned into the pGEM-T easy vector to produce pGEM-CP construct that was transformed into E. coli strain $\mathrm{DH}_{5} \alpha$. After digestion of pGEM-CP with Hind III and Bam HI, the released CP gene fragment was gel purified from agarose using a Qiaquick gel extraction kit (Qiagen) according to the manufacturer's instructions and ligated to a similarly digested expression vector pRSET-A (Invitrogen) containing N-terminal hexa-histidine (6x His tag) which tags the expressed protein facilitating easier purification by affinity chromatography. The resulting recombinant plasmid $\mathrm{pR}$ CP (pRSET vector containing the CP gene) was subsequently transformed into the $E$. coli strain $\mathrm{DH}_{5} \alpha$. Transformants were screened by digesting recombinant plasmids with Hind III and Bam $\mathrm{HI}$ and potential recombinants were sequenced using the universal forward and reverse primers to confirm the integrity of the cloned $\mathrm{CP}$ gene. For the expression of the $\mathrm{CP}$, pR-CP construct was transformed into E. coli strain BL21 (DE3) pLys S (Novagen).

\section{Expression of coat protein in $\boldsymbol{E}$. coli and purification of} fusion protein. Induction of the expression of $\mathrm{CP}$ was optimized as described by Sambrook and Russell (2001). $500 \mathrm{ml}$ of Luria-Bertani broth containing $50 \mu \mathrm{g} / \mathrm{ml}$ ampicillin was inoculated with $1 \%$ overnight culture of BL21 cells harboring pR-CP construct and grown at $37^{\circ} \mathrm{C}$. When the bacterial suspension reached $\mathrm{OD}_{600 \mathrm{~nm}}$ of approximately 0.6 , the cells were induced with $1.0 \mathrm{mM}$ IPTG and harvested $3 \mathrm{~h}$ later. The cells were re-suspended in lyses/binding buffer (50 $\mathrm{mM} \mathrm{NaH} \mathrm{PO}_{4}, 10 \mathrm{mM}$ Tris $\mathrm{Cl}, 100 \mathrm{mM} \mathrm{NaCl}, 0.1 \%$ SDS and $0.1 \%$ Triton $\mathrm{X}-100, \mathrm{pH} 8.0$ ) and frozen at $-20^{\circ} \mathrm{C}$ for overnight. After thawing to room temperature, the cells were sonicated for further disruption and the cell lysate was subjected to centrifugation at $12000 \mathrm{rpm}$ for $10 \mathrm{~min}$ to separate soluble and insoluble fractions. The supernatant was mixed with $1 \mathrm{ml}$ of Ni-NTA resin (Invitrogen), which had been pre-equilibrated with the binding buffer at $4{ }^{\circ} \mathrm{C}$ for $30 \mathrm{~min}$, and allowed to rotate in the shaker for $45 \mathrm{~min}$ to facilitate the protein binding to the resin. A column prepared with the above protein-resin complex was washed extensively with the wash buffer $\left(20 \mathrm{mM} \mathrm{NaH}_{2} \mathrm{PO}_{4}, 10 \mathrm{mM}\right.$ Tris $\mathrm{Cl}, 500 \mathrm{mM} \mathrm{NaCl}, 0.1 \%$ SDS and $0.1 \%$ Triton $\mathrm{X}-100$, $\mathrm{pH} 6.0$ ) till the absorbance of the washings at $280 \mathrm{~nm}$ was negligible. The bound protein was then eluted with elution buffer $\left(20 \mathrm{mM} \mathrm{NaH} \mathrm{PO}_{4}, 10 \mathrm{mM}\right.$ Tris $\mathrm{Cl}, 500 \mathrm{mM} \mathrm{NaCl}$, $0.1 \%$ SDS and $0.1 \%$ Triton X-100, $\mathrm{pH} 4.0$ ) into $1 \mathrm{ml}$ fractions. Fractions were analyzed by $10 \%$ SDS-PAGE (Laemmli, 1970) and the protein in each fraction was estimated by UV-Spectrophometry. The fractions containing a protein concentration greater than $0.1 \mathrm{mg} / \mathrm{ml}$ were pooled and dialyzed for 24-36 h to remove free SDS against $5 \mathrm{mM}$ Tris-HCl buffer, $\mathrm{pH}$ 8.0, containing $0.5 \mathrm{mM}$ EDTA. The renatured protein was concentrated by using centrifugal filter (PALL life sciences) with $10-\mathrm{kDa}$ molecular weight cut off membrane.

Western blot analysis and production of antiserum to recombinant CP. Ni-NTA column purified protein, healthy and PRSV infected papaya total leaf proteins were resolved on $10 \%$ SDS-PAGE and transferred to nitrocellulose membrane as described by Towbin et al. (1979) using semidry blotter (Millipore). The proteins on the membrane were probed with antibodies raised against purified PRSV-W virions followed by detection with alkaline phosphatase conjugated anti-rabbit antibody. The membrane blots were developed using the BCIP/NBT colorimetric system (Bangalore Genei, India). Polyclonal antibodies were raised against purified recombinant coat protein (rCP) by immunizing 3 to 4 months old New Zealand white rabbit weekly for four weeks. All injections were given intramuscularly into the thigh muscles of both legs alternatively. $1 \mathrm{mg}$ of $\mathrm{rCP}$ in $500 \mu \mathrm{l}$ was emulsified with an equal volume of Freund's complete adjuvant for the first injection and this was followed by three injections of $600 \mu \mathrm{g}$ in Freund's incomplete adjuvant. The antiserum was collected from rabbit weekly for eight weeks starting from one week after the last injection and tested reactivity and specificity by western blotting and SDS- immuno diffusion tests using purified rCP and partially purified PRSV infected leaf antigens.

\section{Development of IC-RT-PCR for detection of PRSV iso-} lates. IC-RT-PCR was performed as described by Nolasco et al. (1993). Healthy and PRSV infected leaf extracts were prepared by grinding tissue in $500 \mathrm{mM}$ Tris- $\mathrm{HCl}, \mathrm{pH} 8.2$ containing $2 \%$ polyvinyl pyrrolidone, MW 40,000; $0.01 \mathrm{M}$ $\mathrm{Na}_{2} \mathrm{SO}_{3} ; 3 \mathrm{mM} \mathrm{NaNO} ; 140 \mathrm{mM} \mathrm{NaCl}$ and $0.05 \%$ Tween 20 at a rate of $1 \mathrm{~g} / 9 \mathrm{ml}$. The extracts were clarified by centrifugation at $10,000 \mathrm{rpm}$ for $5 \mathrm{~min}$. Immunocapture of virions was carried out using a coating and trapping method adapted from Clark and Adams (1977). Clarified PRSV infected and healthy leaf extract at 1:10 dilution was added to sterile PCR tubes ( $50 \mu \mathrm{l} /$ tube) that had been previously coated with $\mathrm{rCP}$ antiserum $(1: 1000)$ diluted in coating buffer. After an overnight incubation at $4{ }^{\circ} \mathrm{C}$, the tubes were 
washed thrice with PBS-T and once with sterile distilled water. Immunocaptured tubes were incubated with Oligo (dT) primer $\left(2.5 \mu \mathrm{M}\right.$ final conc.) at $80^{\circ} \mathrm{C}$ for $10 \mathrm{~min}$ and snap chilled on ice. cDNA was synthesized in a $20 \mu \mathrm{l}$ reaction mix using M-MuLV reverse transcriptase (Fermentas). PCR was performed using a $5 \mu \mathrm{l}$ aliquot of the cDNA mix as template and 10 pmoles each of the CP-F and $\mathrm{CP}-\mathrm{R}$ primers under the conditions as described above for the $\mathrm{CP}$ amplification. The amplified products were analyzed by $1 \%$ agarose gel (Sambrook et al., 1989). Seven PRSV isolates collected from states of south India were tested as described above.

Comparison of IC-RT-PCR with ELISA and DBIA. To test the sensitivity levels of IC-RT-PCR in detection of PRSV, comparative analyses was carried out with double antibody sandwich (DAS) \& direct antigen coating (DAC) ELISA and dot-blot immunobinding assay (DBIA) using serial dilutions of PRSV infected leaf sap. Healthy and PRSV-APRa isolate infected leaf extracts were prepared by grinding tissue in $0.1 \mathrm{M}$ carbonate bicarbonate buffer, $\mathrm{pH}$ 9.6 (for DAC-ELISA and DBIA) or in $500 \mathrm{mM}$ Tris-HCl, pH 8.2 containing $2 \%$ polyvinyl pyrrolidone, MW 40,000; $0.01 \mathrm{M} \mathrm{Na}_{2} \mathrm{SO}_{3} ; 3 \mathrm{mM} \mathrm{NaNO} ; 140 \mathrm{mM} \mathrm{NaCl}$ and $0.05 \%$ Tween 20 (for DAS-ELISA and IC-RT-PCR) at a rate of 1 $\mathrm{g} / 9 \mathrm{ml}$. Dilutions ranging from $10^{-1}$ to $10^{-4}$ of clarified extract were tested by IC-RT-PCR as described above.

The DAC- and DAS-ELISA methods were done essentially as described by Clark and Adams (1977) and Hobbs et al. (1987), respectively. A $200 \mu \mathrm{l}$ aliquot was used at each step and each sample was duplicated. Plates were coated with different dilutions ranging from $10^{-1}$ to $10^{-4}$ of PRSV infected leaf extracts. Healthy leaf extract of same dilutions were used as negative controls. In DAS-ELISA, the plate was initially coated with $1 / 1000$ dilution of recombinant coat protein $(\mathrm{rCP})$ antiserum and in both types of ELISA, antigens were detected with $1 / 10,000$ dilution of antiserum. 1/10,000 dilution of Alkaline phosphatase-conjugated antirabbit IgG (Bangalore Genei, India) was used to reveal the antigen-antibody complex, and the substrate, di-sodium pnitrophenyl phosphate (Sigma), diluted to $1 \mathrm{mg} / \mathrm{ml}$ in substrate buffer $(10 \%$ diethanolamine, $\mathrm{pH} 9.8)$ was added to the plates. Colour reactions were stopped using $3 \mathrm{~N} \mathrm{NaOH}$ and the absorbance measured at $405 \mathrm{~nm}$ with a Bio-Rad Model 680 Microplate reader. Infected and healthy absorbance ratios ( $\mathrm{I} / \mathrm{H}$ ratios) were calculated on mean values of absorbance for each antigen dilution. $\mathrm{I} / \mathrm{H}$ ratios were plotted against each antigen dilution. A positive-negative threshold was set for plate as two times the value of the O.D. of healthy control $(\mathrm{I} / \mathrm{H}=2)$ for each dilution.

DBIA was performed as described by Berger et al. (1985). The clarified PRSV infected leaf extract dilutions $\left(10^{-1}\right.$ to $\left.10^{-4}\right)$ were doted on nitrocellulose membrane strip. $1 / 10$ dilution of healthy leaf extract was used as negative control. 1/10,000 dilution of $\mathrm{rCP}$ antibodies were used as primary antibodies and ALP- labeled goat anti rabbit antibodies as secondary antibodies. Substrate was BCIP/ NBT for ALP system.

\section{Results}

Amplification, cloning and sequencing of the 3 ' terminal region of PRSV genome. The 3 ' terminal region of the genome of PRSV isolate APRa was amplified with a primer pair "PRSV-F/PRSV-R" on the cDNA by PCR, which yielded a product of approximately $1.7 \mathrm{kbp}$ fragment, and no such amplification, was observed on cDNA of healthy papaya tissue. Ligation of amplicons into pGEM-T easy vector resulted in the recombinant clone (pGEM-APRa). The sequence data revealed that the 3 ' terminal region contained a single ORF encoding a polyprotein that included a C-terminal part of the $\mathrm{NIb}$ protein and complete $\mathrm{CP}$. The ORF was followed by an UTR of 209 nucleotides excluding the poly (A) tail.

Expression of PRSV CP and production of its antiserum. PCR on pGEM-APRa clone with a primer pair of $\mathrm{CP}-\mathrm{F}$ and CP-R yielded a product of $919 \mathrm{bp}$ fragment, which contains the complete $\mathrm{CP}$ coding sequence and Bam HI \& Hind III restriction sites at 5' \& 3' ends, respectively. After sub cloning the Bam HI/Hind III digested CP coding region into the similarly digested expression vector pRSETA, the protein was expressed in E. coli strain BL21 (DE3) pLys $\mathrm{S}$ by inducing with $1 \mathrm{mM}$ IPTG. A protein of about 40 $\mathrm{kDa}$ in size was detected by SDS-PAGE in lysate of induced BL21 cells harboring pR-CP clone, but not in lysates of non induced bacterial cells with the same plasmid or induced cells containing the pRSET-A vector alone (Fig. 1a). Expressed CP was Ni-NTA column purified and eluted fractions were analysed on SDS-PAGE (Fig. 1b). Western blot analysis showed that the Ni-NTA column purified 40 $\mathrm{kDa}$ protein and $36 \mathrm{kDa}$ viral $\mathrm{CP}$ in extracts PRSV infected leaf were reacted with antibodies produced against purified PRSV particles whereas no protein in the extracts of healthy papaya leaf was reacted, thus confirming the homology of the expressed protein to the native PRSV CP (Fig. 1c).

Polyclonal antiserum to the PRSV rCP was successfully prepared by injecting a rabbit with a total of $2.5-3.0 \mathrm{mg}$ recombinant coat protein. After four weekly injections, antiserum was collected and tested its reactivity and specificity by SDS-immunodiffusion test. The antiserum reacted strongly with Ni-NTA column purified protein and with native CP of PRSV in infected papaya leaf extract, but not reacted 
(a)

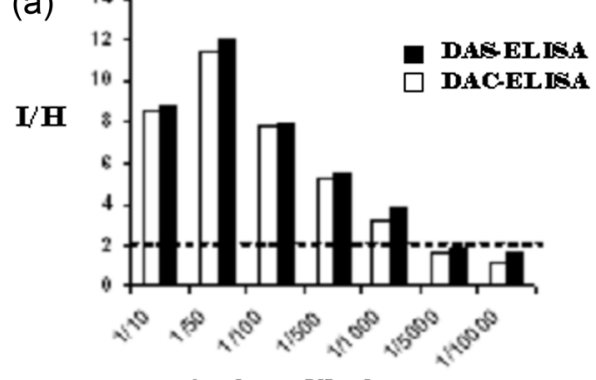

Antigen dilution

(b)

\begin{tabular}{|llllllll|}
\hline H & 1 & 2 & 3 & 4 & 5 & 6 & 7 \\
\hline & 0 & 0 & 0 & $*$ & $*$ & $*$ &
\end{tabular}

(c)

$\begin{array}{lllllllllll}M & 1 & 2 & 3 & 4 & 5 & 6 & 7 & 8 & 9 & 10\end{array}$

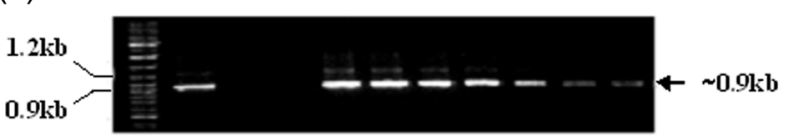

Fig. 1. (a) SDS-PAGE gel showing the expression of PRSV CP in E.coli: M: Protein molecular weight markers (Medium Range; Banglore Genei, India); Lane 1, Induced E. coli BL21 carrying pRSET-A vector alone; 2 , Induced $E$. coli BL21 with pR-CP; 3, Uninduced E. coli BL21 with pR-CP; (b) SDS-PAGE gel showing Ni-NTA affinity purification of expressed CP. M: Protein markers; Lane 1-8, Fractions of eluted CP; (c) Western blot analysis of the PRSV CP expressed in E. coli. Lane 1. PRSVAPRa infected papaya leaf proteins; 2, Ni-NTA column purified $\mathrm{CP} ; 3$, Healthy papaya leaf proteins.

with proteins in healthy leaf extract (data not shown).

Detection of PRSV by IC-RT-PCR and comparison of its sensitivity with other immunoassays. The $\mathrm{rCP}$ antibody based IC-RT-PCR was successfully developed and tested for detection of PRSV isolates. The predicted size of DNA product ( 900$)$ was amplified from all seven isolates tested, but no such amplification was observed in extracts from healthy papaya (Fig. 2). The antiserum raised against rCP was assayed in ELISA, DBIA and IC-RT-PCR using serial dilutions $\left(10^{-1}-10^{-4}\right)$ of PRSV-AP Ra isolate infected

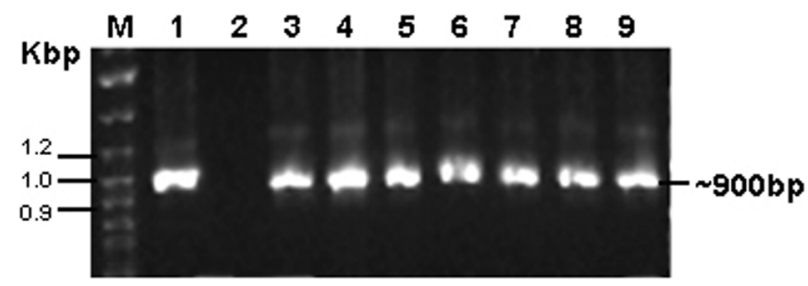

Fig. 2. Diagnosis of PRSV isolates collected from different geographical locations in south India by IC-RT-PCR using rCP antiserum and a primer pair CP-F and CP-R. Lanes 3-9. PRSV isolates APRa, APTe, APKo, TATi, KAGu, KAHo and KECa, respectively. Lane 1 . Positive control. Lane 2 . Healthy papaya. M: DNA ladder (GeneRuler ${ }^{\mathrm{TM}}$ DNA Ladder Mix, 100-10,000 bp; Fermentas).

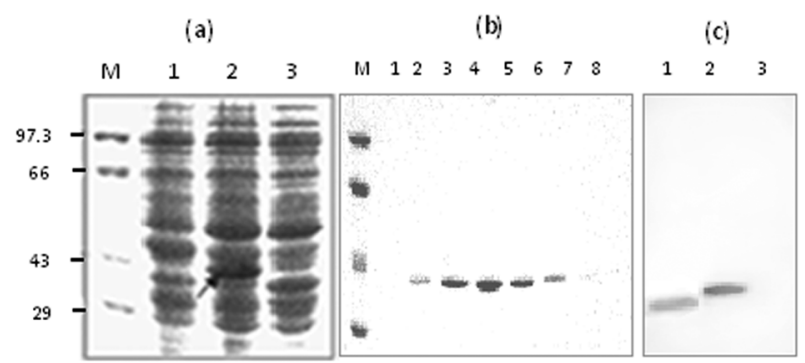

Fig. 3. Comparison of the sensitivities of assays for detection of PRSV (a) Detection limits of DAC- and DAS ELISA. Results were presented as O.D. ratios between the infected and healthy sample $(\mathrm{I} / \mathrm{H})$. The horizontal dotted line at $\mathrm{I} / \mathrm{H}=2$ represents the set positive-negative threshold. (b) DBIA analysis: $\mathrm{H}$ : healthy leaf extract at 1/10 dilution; Lane 1-7: PRSV infected papaya leaf extracts at $1 / 10,1 / 50,1 / 100,1 / 500,1 / 1000,1 / 5000$ and 1/10000 dilutions, respectively. (c) IC-RT-PCR analysis: M: DNA ladder (GeneRuler ${ }^{\mathrm{TM}}$ DNA Ladder Mix, 100-10,000 bp; Fermentas); Lane 1 positive control; lane 2 PCR without template DNA; lane 3 healthy leaf extract at $1 / 10$ dilution; lane 4-10 PRSV infected papaya leaf extracts at 1/10,1/50,1/100,1/500,1/1000, 1/5000 and $1 / 10000$ dilutions, respectively.

papaya leaf sap. The predicted size of DNA product ( 900$)$ was seen in IC-RT-PCR analysis using PRSV infected leaf extract dilutions of up to $1 / 10000$ and such a specific product was not found in healthy control (Fig. 3c). In DBIA, the antiserum gave a positive reaction in dots of infected leaf tissues and no color development in dots of healthy

Table 2. Comparison of the sensitivity of ELISA, DBIA and IC-RT-PCR to detect PRSV in infected leaf extract

\begin{tabular}{|c|c|c|c|c|c|c|c|c|}
\hline & Healthy $^{\mathrm{a}}$ & $1 / 10$ & $1 / 50$ & $1 / 100$ & $1 / 500$ & $1 / 1000$ & $1 / 5000$ & $1 / 10000$ \\
\hline DAC-ELISA & $-^{\mathrm{b}}$ & ++ & $+++^{\mathrm{c}}$ & $++^{\mathrm{d}}$ & ++ & $+^{e}$ & - & - \\
\hline DAS-ELISA & - & ++ & +++ & ++ & ++ & + & - & - \\
\hline DBIA & - & +++ & +++ & ++ & + & + & + & - \\
\hline IC-RT-PCR & - & +++ & +++ & +++ & ++ & ++ & + & + \\
\hline
\end{tabular}

${ }^{\mathrm{a}}$ Healthy papaya

${ }^{\mathrm{b}}$ Negative result or $\mathrm{I} / \mathrm{H}$ ratio less than two or no dot on membrane or no band on the gel.

${ }^{\mathrm{c}} \mathrm{I} / \mathrm{H}$ ratio more than ten or strongly reacted dot on the membrane or a strong band on the gel.

${ }^{\mathrm{d}} \mathrm{I} / \mathrm{H}$ ratio greater than five but less than ten or dot on the membrane or a band on the gel with moderate intensity.

${ }^{\mathrm{e}} \mathrm{I} / \mathrm{H}$ ratio greater than twice but less than five or dot on the membrane with less intensity or a weak band on the gel. 
plant tissues (Fig. 3b). Though the dilution end point of the infected leaf sap in reacting with $\mathrm{rCP}$ antiserum in both types of ELISA was same, in DAS-ELISA high $\mathrm{I} / \mathrm{H}$ values were obtained for all dilutions (Fig. 3a). The results demonstrate the higher sensitivity of IC-RT-PCR when compared to two types of ELISA methods and DBIA. The detection limit for ELISA and DBIA were found to be 1/1000 and 1/ 5000 respectively, while IC-RT-PCR was able to detect PRSV at all dilutions including the highest dilution of 1/ 10000 (Table 2). The sensitivity of DBIA was found to be five times more than that of ELISA and the sensitivity of IC-RT-PCR was appeared to be ten-fold and two-fold more than those of both types of ELISA and DBIA, respectively.

\section{Discussion}

The increasing number of viral sequences available in databases and wide spread use of PCR has enabled many scientists to amplify and clone viral genes into expression vectors, purify the recombinant proteins and use them for producing antibodies. In plant virology, this approach has been applied for detection and localization of several non structural viral proteins (Kallender et al., 1988; Kormelink et al., 1994; van Poelwijk et al., 1993; Mullineaux et al., 1988) and also for production of polyclonal antibodies against several viruses that are less stable and difficult to purify from plant material (Abouzid et al., 2002; Hema et al., 2003; Hourani and Abou-Jawdah, 2003; Ling et al., 2000; Nikolaeva et al., 1995; Targon et al., 1997). In this study, we also successfully cloned the PRSV CP gene, efficiently expressed in a bacterial expression system and used it to produce a high titre PRSV-specific polyclonal antiserum. The cloning strategy used for construction of pR-CP clone resulted in the addition of 36 amino acids to the $\mathrm{N}$-terminus of CP sequence ( 34 from pRSET-A vector and 2 from sense primer). Hence the $\mathrm{CP}$ was expressed as a fusion protein with an estimated MW of about $40 \mathrm{kDa}$, which is about $4 \mathrm{kDa}$ more than expected MW of $36 \mathrm{kDa}$. The additional 36 amino acids at the N-terminus of the expressed CP did not affect its antigenicity, which is indistinguishable from the native viral $\mathrm{CP}$.

The bacterially expressed PRSV CP was proved to be good immunogen, yielding antiserum comparable to the antiserum produced against purified PRSV virions (data not shown). The titer of the antiserum against PRSV, as determined by indirect DAC-ELISA, reached approximately $10^{-7}$ four weeks after the last injection and the results obtained with the above three detection methods showed that the antibodies produced against recombinant $\mathrm{CP}$ fusion protein are of good quality and specificity for diagnosis of PRSV. The antiserum at 1/10,000 dilution could detect PRSV in infected plant extracts by both plate trapped and dot ELISA methods without perceptible background and this dilution was selected for routine application. The ICRT-PCR was the method of choice for detecting low concentrations of PRSV in papaya and in various cucurbits as this method was reported to be more sensitive than ELISA and DBIA and could detect the virus in leaf extracts of at least $10^{4}$ dilution. Though the ELISA methods were found to be less sensitive than DBIA and IC-RT-PCR in detection of PRSV, still the ELISA methods were able to detect PRSV in infected sap of dilution $1 / 1000$. This demonstrates the applicability of ELISA for batch testing of samples. In addition to field diagnosis, the rCP antiserum can be useful in breeding programs, both traditional and transgenic approaches that are used for production of PRSV resistant papaya verities.

\section{Acknowledgements}

The authors are grateful to Dr. J. A. M. Rezende, Departmento de Entomologia e Zoologia Agricola, Universidade de Sao Paulo, Brazil for providing antiserum of PRSV-W. This research was funded by University Grants Commission, Govt. of India [31-254/2005 (SR), Dt. 31/03/2006].

\section{References}

Abouzid, A. M., Freitas-Astua, J., Purcifull, D. E., Beckham, K. A., Crawford, W. E., Peterson, M. A., Peyser, B., Patte, C. and Heibert, E. 2002. Serological studies using polyclonal antisera prepared against the viral coat protein of four Begomoviruses expressed in Escherichia coli. Plant Dis. 86:1109-1114.

Berger, P. H., Thornbury, D. W. and Pirone, T. P. 1985. Detection of pictogram quantities of potyviruses using dot-blot immunobinding assay. J. Gen. Virol. 12:31-36.

Capoor, S. P. and Varma, P. M. 1958. A mosaic disease of papaya in Bombay. Indian. J. Agri. Sci. 29:225-233.

Clark, M. F. and Adams, A. N. 1977. Characteristics of the microplate method of enzyme- linked immunosorbent assay for the detection of plant viruses. J. Gen. Virol. 34:475-483.

Gonsalves, D. 1998. Control of Papaya ringspot virus in papaya: a case study. Ann. Rev. Phytopathol. 36:415-437.

Gonsalves, D. and Ishii, M. 1980. Purification and serology of Papaya ringspot virus. Phytopathology 73:1028-1032.

Hema, M., Kirthi, N., Sreenivasulu, P. and Savithri, H. S. 2003. Development of recombinant coat protein antibody based ICRT-PCR for detection and discrimination of Sugarcane streak mosaic virus isolates from Southern India. Arch. Virol. 148: $1185-1193$

Hobbs, H. A., Reddy, D. V. R., Rajeswari, R. and Reddy, A. S. 1987. Use of direct antigen coating and protein A coating ELISA procedures for detection of three peanut viruses. Plant Dis. 71:747-749.

Hourani, H. and Abou-jawdah, Y. 2003. Immunodiagnosis of Cucurbit yellow stunting disorder virus using polyclonal anti- 
bodies developed against recombinant coat protein. J. Plant Pathol. 85:197-204.

Hussain, S. and Varma, A. 1994. Occurrence of Papaya ringspot virus from Amritsar (Punjab) India. J. Phytopathol. Res. 7:7778.

Kallender, H., Petty, I. T. D., Stein, V. E., Panico, M., Blench, I. P., Etienne, A. T., Morris, H. R., Coutts, R. H. A. and Buck, K. W. 1988. Identification of the coat protein gene of Tomato golden mosaic virus. J. Gen. Virol. 69:1351-1357.

Kormelink, R., Storms, M., van Lent, J., Peters, D. and Goldbach, R. 1994. Expression and sub cellular location of the NSm protein of Tomato spotted wilt virus (TSWV), a putative viral movement protein. Virology 200:56-65.

Laemmli, U. K. 1970. Cleavage of structural proteins during the assembly of the head of the bacteriophage T4. Nature 227:680-685.

Ling, K. S., Zhu, H. Y., Jiang, Z. Y. and Gonsalves, D. 2000. Effective application of DAS-ELISA for detection of Grapevine leafroll associated closterovirus-3 using a polyclonal antiserum developed from recombinant coat protein. Eur. J. Plant Pathol. 106:301-309.

Mullineaux, P. M., Boulton, M. I., Bowyer, P., van der Vlugt, R., Marks, M., Donson. J. and Davies, J. W. 1988. Detection of a non-structural protein of Mr. 11000 encoded by the virion DNA of maize streak virus. Plant Mol. Biol. 11:57-66.

Mumford, R. A. and Seal, S. E. 1997. Rapid single tube immuno capture RT-PCR for the detection of two Yam potyviruses. $J$. Virol. Methods 69:73-79.

Nikolaeva, O. V., Karasev, A. V., Gumpf, D. J., Lee, R. F., Garnsey, S. M. 1995. Production of polyclonal antisera to the coat protein of Citrus tristeza virus expressed in Escherichia coli: application for immunodiagnosis. Phytopathol. 85:691-694.

Nolasco, G., de Blas, C., Torres, V. and Ponz, F. 1993. A method combining immunocapture and PCR amplification in a microtitre plate for the detection of plant viruses and subviral pathogens. J. Virol. Methods 45:201-218.
Purcifull, D. E., Edwardson, J. R., Hiebert, E., Gonselves, D. 1984. Papaya ringspot virus. CMI/AAB Descriptions of Plant Viruses no: 292. Wallingford, UK: CAB International.

Sambrook, J., Fritsch, E. F. and Maniatis, T. 1989. Molecular cloning: a laboratory manual. $2^{\text {nd }}$ ed. Cold Spring Harbor Laboratory Press, Cold Spring Harbor, NY, USA.

Sambrook, J. and Russell, D. W. 2001. Molecular Cloning: a laboratory manual. $3^{\text {rd }}$ ed. Cold Spring Harbor Laboratory Press, Cold Spring Harbor, NY, USA.

Targon, M. L. P. N., Nikolaeva, O., Manjunath, K. L. K., Lee, R. F. and Machado, M. A. 1997. Cloning and expression in E.coli of CTV coat protein gene and production of polyclonal antisera. Fitopatologia Brasileira 22:99-102.

Towbin, H., Staehelin, T. and Gordon, J. 1979. Electrophoretic transfer of protein from polyacrylamide gels to nitrocellulose sheets: procedure and some applications. Proc. Natl. Acad. Sci. USA 76:4350-4354.

Varma, A. 1988. The economic impact of filamentous plant viruses-The Indian sub-continent. In: The plant viruses, ed. by R.G. Miline, pp. 371-376. Plenum Press, NY, USA.

van Poelwijk, F., Boye, K., Oosterling, R., Peters, D. and Goldbach, R. 1993. Detection of the L protein of tomato spotted wilt virus. Virology 197:468-470.

van Regenmortel, M. H. V., Fauquet, C. M., Bishop, D. H. L., Carstens, E., Lemon, S., Maniloff, J., Mayo, M. A., McGeoch, D., Pringle, C. R. and Wickner, R. B. 2000. Virus taxonomy. Seventh report of the International committee on taxonomy of viruses. Academic press, New York, USA.

Yeh, S. D., Jan, F. J., Chiang, C. H., Doong, T. J., Chen, M. C., Chung, P. H. and Bau, H. J. 1992. Complete nucleotide sequence and genetic organisation of Papaya ringspot virus RNA. J. Gen. Virol. 73:2531-2541.

Yeh, S. D., Gonsalves, D. and Providenti, R. 1984. Comparative studies on host range and serology papaya ringspot and watermelon mosaic virus. Phytopathol. 74:1081-1085. 